\title{
Dexmedetomidine Versus Neostigmine in Addition to Bupivacaine for Caudal Analgesia in Pediatrics Undergoing Congenital Inguinal Hernia Repair
}

\author{
HANI M. OMAR, M.Sc.; LOBNA M. ABO EL-NASR, M.D.; ASHARF E. EL-ZEFTAWY, M.D. and \\ GEHAN M. EID, M.D.
}

The Department of Anesthesiology and Surgical Intensive Care, Faculty of Medicine, Tanta University

\begin{abstract}
Background: Post-operative pain management in children is a necessity for both medical and ethical reasons. Caudal block is one of the oldest and the most popular regional block in pediatric anesthesia. Dexmedetomidine is a specific $\alpha 2$ adrenergic receptor agonist with sedative, anxiolytic, and analgesic properties. Respiratory depression, sedation and pruritis ascribed to the use of caudal opioids are not encountered with neostigmine.
\end{abstract}

Aim of Study: Our aim is to compare the effect of dexmedetomidine versus neostigmine in addition to bupivacaine for caudal analgesia in pediatrics undergoing congenital inguinal hernia repair.

Methods and Material: This study was carried out on 90 children, 1-6 years, ASA I-II, scheduled for congenital inguinal hernia repair. Patients were randomly classified into 3 equal groups, 30 patients each, caudal block with a total volume of $0.5 \mathrm{ml} / \mathrm{kg}$ Group I: Bupivacaine $0.25 \%$, Group II: $0.25 \%$ bupivacaine and dexmedetomidine $2 \mathrm{gg}$ and Group III: $0.25 \%$ bupivacaine with neostigmine $2 \mathrm{~g} / \mathrm{g}$ in. HR, MAP and $\mathrm{SpO}_{2}$ were recorded at baseline \& 15 ( 5 minutes after caudal), 25, 35, 45, 60min after induction of anesthesia \& 5, $30,60 \& 120 \mathrm{~min}$ after recovery. Pain score was recorded at $1,2,4,6,24 \mathrm{hr}$ after recovery using the FLACC Behavioral Scale, number of patients who needed rescue analgesia in the 1 st $24 \mathrm{hr}$ ' post-operative. Rescue analgesia was administered at FLACC score $\leq 4$, total amount of acetaminophen within the $1 \mathrm{st} 24 \mathrm{~h}$, time till administration of first rescue analgesia $\&$ any undesirable side effects.

Results: HR and MAP were statistically non-significant difference in the three groups, but it was statistically significant difference between the pre-operative HR and MAP and at $25 \mathrm{~min}$. FLACC behavioral pain score \& total does of analgesia was significantly lower in group II than in group III than in group I. The time of first rescue analgesia was earlier in group I than in group III than in group II.

Conclusions: Addition of dexmedetomidine or neostigmine to bupivacaine in a dose of $2 \mathrm{~g} / \mathrm{lg}$ results in superior analgesia

Correspondence to: Dr. Hani M. Omar, The Department of Anesthesiology and Surgical Intensive Care,

Faculty of Medicine, Tanta University than bupivacaine alone. But dexmedetomidine had better analgesic effect than addition of neostigmine to bupivacaine.

Key Words: Inguinal hernia repair - Caudal analgesia Dexmedetomidine.

\section{Introduction}

POST-OPERATIVE pain management in children is a necessity for both medical and ethical reasons; it increases patient satisfaction and shortens hospital stay [1].

Caudal epidural block is one of the oldest and the most popular regional block performed in pediatric anesthesia [2] . It provides excellent intraoperative and post-operative analgesia in patients undergoing short surgical procedures below the umbilicus [3]. It allows rapid recovery from anesthesia by reducing the requirement of other systemic anesthetic agents with effective postoperative analgesia [4]. But, one of the major disadvantages with caudal analgesia is the limited duration of analgesia following single injection [5]. To prolong the duration of action and to improve the quality of intra-operative and postoperative analgesia of local anesthetics, various adjuvants like morphine, fentanyl, clonidine, ketamine and neostigmine have been used [6] .

Dexmedetomidine is a specific $\alpha 2$ adrenergic receptor agonist with sedative, anxiolytic, and analgesic properties which enables it to prevent emergence agitation in children [7]. Recent studies suggested that caudal administration of dexmedetomidine could prolong postoperative pain relief in children $[8]$.

Neostigmine has been safely used in adults and children. It does not require specific preservative 
free preparations as it's preservatives, methyl and propyl-parabens, have been safely used. In addition, respiratory depression, sedation and pruritis ascribed to the use of caudal opioids are not encountered with caudal neostigmine [9].

\section{Material and Methods}

This study was carried out in Tanta University Hospitals during 2017 Pediatric Surgery Department. The study included ninety pediatric patients, aged 1-6 years, ASA physical status I-II of both sex scheduled for congenital inguinal hernia repair. An informed consent was obtained from parents of participants after approval of our institutional review board. Exclusion criteria were: Parent refusal, contraindication to caudal block, e.g. meningiocele, infection at the site of injection, abnormality of vertebral column, raised intracranial pressure, uncorrected hypovolemia and coagulopathy.

Patients were randomly classified into 3 equal groups, 30 patients each, using a computergenerated random: Group I: (n=30 patients) "caudal block with bupivacaine $0.25 \%$ (Markyrene, Sigma, U.K.) only" received a caudal injection of $0.25 \%$ bupivacaine in a total volume of $0.5 \mathrm{~mL} / \mathrm{kg}$. Group II: ( $\mathrm{n}=30$ patients) "Caudal block with bupivacaine \& dexmedetomidine" (Precede, Hospira, USA) received a caudal injection of $0.25 \%$ bupivacaine and dexmedetomidine $2 \mu \mathrm{g} / \mathrm{kg}$ [10] in a total volume of $0.5 \mathrm{~mL} / \mathrm{kg}$. (precedex amp 200mic/2ml) and Group III: ( $\mathrm{n}=30$ patients) "Caudal block with bupivacaine \& neostigmine" (Neostigmine Methylsulfate, Biologici, Italy) received a caudal injection of $0.25 \%$ bupivacaine mixed with neostigmine $2 \mu \mathrm{g} / \mathrm{kg}$ [9] in a total volume of $0.5 \mathrm{~mL} / \mathrm{Kg}$.

Patient's allocation to either group was saved in a sealed opaque envelope. An Anesthesiologist who had no subsequent involvement in the study opened the envelope and prepared the materials to be injected on a sterile spinal table covered by a sterile drape. The researcher gave the caudal block without knowing the contents of the syringe. For all patients, full clinical examination and laboratory investigations were done.

Anesthetic technique: On arrival to the OR, the patient was connected to monitor through pulseoximeter, Electrocardiogram (ECG), Noninvasive Blood Pressure (NIBP), and temperature probe. Inhalational induction of anesthesia was carried out using sevoflurane $5 \%$ in $100 \%$ oxygen followed by insertion of an IV line (22 or 24-gauge cannula) and endotracheal intubation. Capnometer was con- nected to the tube after intubation. Maintenance of anesthesia was done by sevoflurane $3 \%$ in $100 \%$ $\mathrm{O}_{2}$. The patients were allowed to breathe spontaneously. Fluid maintenance with Saline/D5W (50\%:50\%) at a rate of $2-3 \mathrm{ml} / \mathrm{kg}$.

\section{Technique of caudal block:}

After induction of anesthesia, left lateral position was obtained with the upper hip flexed $90^{\circ}$, the lower one only $45^{\circ}$. The investigator sterilized his hands, wore sterilized gloves and gown, and swabbed the patient's lower back in a craniocaudal direction with betadine solution. The back of the patient was covered with sterile drapes leaving the area over sacral hiatus which was felt as a groove or notch above the coccyx and between two bony prominences; the sacral cornu.

The index finger of the left hand was put over the upper part of the sacral hiatus and epidural puncture was done with the right hand in the most proximal region of the sacral hiatus with the needle inclined $45^{\circ}$ to $60^{\circ}$ to the skin. Penetration of the sacrococcygeal ligament which occludes the sacral hiatus, was identified by sensing a release as the needle passes into the epidural space. Once in the epidural space the needle was minimally advanced, no more than 1 to $3 \mathrm{~mm}$ to avoid a bloody puncture or an intrathecal injection. Negative aspiration was done to exclude presence of the needle tip in a vessel or CSF. The medication was administered incrementally every 20 to 30 seconds over a few minutes while monitoring vital signs for evidence of IV or intrathecal administration. Any resistance to injection was interpreted as incorrect position of the needle. The index finger of the left hand was palpating the skin cephalad to the needle to ensure that local anesthetic was not injected subcutaneously.

The following data were recorded: Heart rate, mean arterial blood pressure and $\mathrm{SpO} 2$ were recorded before induction of anesthesia (baseline), $15,30,60$ minutes after induction of anesthesia \& $5,30,60$ and 120 minutes after recovery. Pain score was recorded at 1, 2, 4, 6, 24 hours after recovery using the FLACC Behavioral Scale. Zero indicates no pain and 10 indicates the worst pain. Table (1) number of patients who needed rescue analgesia in the ${ }^{1 \text { st }} 24$ hours' post-operative. Rescue analgesia was administered at FLACC score $<4$ in the form of acetaminophen suppository $15 \mathrm{mg} / \mathrm{kg}$ every 6 hours. Total amount of acetaminophen within the $1 \mathrm{st} 24 \mathrm{~h}$ was recorded. Time till administration of first rescue analgesia. Any undesirable side effects as bradycardia (a decrease in heart rate of more than $30 \%$ of the baseline), vomiting, uri- 
nary retention, or pruritus were recorded. Bradycardia was managed with atropine $0.01 \mathrm{mg} / \mathrm{kg} I V$. Metoclopromide $0.1 \mathrm{mg} / \mathrm{kg}$ was administered for vomiting and dexamethasone $0.5 \mathrm{mg} / \mathrm{kg}$ for pruritus. Urine retention was managed by insertion of urinary catheter.

Sample size calculation was centered around $95 \%$ confidence limit, a power of $80 \%$, number of cases to control is $1: 1 \&$ expected outcome ranging between $50-85 \%$. We estimated that approximately 30 patients would be required for each group. After calculation a dropout ratio of $10 \%$, we included 30 patients in each group.

Statistical analysis was performed using SPSS Version 24 (Statistical Package for Social Studies) created by IBM, Illinois, Chicago, USA. Data were presented as mean \pm standard deviations or number (percentage) where appropriate, numerical data was compared using paired $t$-test in the unpaired same group. Chi-square test was used for comparison of qualitative data. Data was considered significant when $p$-value was $<0.05$.

Table (1): FLACC behavioral score [11]

\begin{tabular}{|c|c|c|c|}
\hline Pain score & 0 & 1 & 2 \\
\hline$F($ face $)$ & $\begin{array}{l}\text { - No special mood or laughing } \\
\text { could be seen. }\end{array}$ & $\begin{array}{l}\text { - Sometimes he frowns and pull } \\
\text { himself back. }\end{array}$ & $\begin{array}{l}\text { - He frowns repeatedly and press } \\
\text { his mandible on each other. }\end{array}$ \\
\hline L (legs) & - Normal position of legs in rest. & $\begin{array}{l}\text { - He is unease and agitated and } \\
\text { contracts his leg a little. }\end{array}$ & $\begin{array}{l}\text { - He kicks his leg \& moves up and } \\
\text { down. }\end{array}$ \\
\hline C (crying) & - No crying (conscious, sleepy). & $\begin{array}{l}\text { - He moans or cry's and sometimes } \\
\text { suffer from pain. }\end{array}$ & $\begin{array}{l}\text { - He always moans \& cry's or } \\
\text { scream. }\end{array}$ \\
\hline A (activity) & $\begin{array}{l}\text { - He sleeps calmly with normal } \\
\text { activity and moves with ease. }\end{array}$ & $\begin{array}{l}\text { - He moves toward back \& forth, } \\
\text { right and left and felt } \\
\text { uncomfortable. }\end{array}$ & $\begin{array}{l}\text { - His limb are bent and his muscle } \\
\text { are contracted with sudden } \\
\text { movement. }\end{array}$ \\
\hline $\mathrm{C}$ (consolability) & - He is calm and comfort. & $\begin{array}{l}\text { - He becomes calm by } \\
\text { embarrassing and pampering him. }\end{array}$ & $\begin{array}{l}\text { - It is difficult to console him and } \\
\text { make him comfort. }\end{array}$ \\
\hline
\end{tabular}

\section{Results}

According to patient's demographic data (age in years and sex), duration of surgery and Total volume $(\mathrm{ml})$ given in caudal block, there was no significant difference among the three groups ( $p$ value $>0.05)$. Table (2).

Heart rate and mean arterial blood pressure were statistically non-significant difference in the three groups but it was statistically significant difference between the pre-operative heart rate and mean arterial blood pressures and at $25 \mathrm{~min}$. Figs. $(1,2)$. There was no a statistically significant difference in $\mathrm{SpO}_{2}$ between the three groups.

Similarly, the FLACC behavioral pain score was significantly lower in group II than in group III than in group I. There was no a statistically significant difference between group I \& group II at $1 \mathrm{hr}, 2 \mathrm{hr}, 6 \mathrm{hr}, 12 \mathrm{hr}, 24 \mathrm{hr}(p$-value $<0.05)$ and There was a statistically significant difference at $4 \mathrm{hr}, 10 \mathrm{hr}$ post-operative ( $p$-value $>0.05$ ). There was no a statistically significant difference between group I \& group III at $1 \mathrm{hr}, 2 \mathrm{hr}, 6 \mathrm{hr}, 10 \mathrm{hr}, 12 \mathrm{hr}$, $24 \mathrm{hr}$. ( $p$-value $<0.05)$ and there was a statistically significant difference at $4 \mathrm{hr}$, post-operative $(p$ value $>0.05$ ). There was no a statistically significant difference between group II \& group III at $1 \mathrm{hr}$, $2 \mathrm{hr}, 4 \mathrm{hr}, 6 \mathrm{hr}, 12 \mathrm{hr}$ and $24 \mathrm{hr}$ post-operative ( $p$ - value $<0.05)$ and there was a statistically significant difference at $10 \mathrm{hr}(p$-value $<0.05)$ Table (3).

The total does of analgesia was significant lower in group II compared to group III and group I and lower in group III than group I. Table (4) The time of first rescue analgesia was earlier in group I than in group III than in group II Table (5).

Table (2): Demographic data (age in years and sex), duration of surgery and total volume $(\mathrm{ml})$ given in caudal block.

\begin{tabular}{lllll}
\hline & $\begin{array}{c}\text { Group I } \\
(\mathrm{n}=30)\end{array}$ & $\begin{array}{c}\text { Group II } \\
(\mathrm{n}=30)\end{array}$ & $\begin{array}{c}\text { Group III } \\
(\mathrm{n}=30)\end{array}$ & $\begin{array}{c}p \text { - } \\
\text { value }\end{array}$ \\
\hline Age (years): & & & & \\
$\quad$ Mean & 3.57 & 3.50 & 3.17 & 0.62 \\
$\quad$ SD & 1.63 & 1.71 & 1.63 & \\
Sex: & & & & \\
$\quad$ Male & 27 & 25 & 26 & 0.74 \\
$\quad$ Female & 3 & 5 & 4 & \\
$\begin{array}{l}\text { Duration of surgery } \\
\text { (min): }\end{array}$ & & & & \\
$\quad$ Mean & & & & \\
$\quad$ SD & 65.43 & 66.87 & 66.17 & 0.48 \\
Total volume (ml) given & & & & \\
in caudal block: & & & & \\
$\quad$ Mean & 7.39 & 4.73 & 4.41 & \\
$\quad$ SD & 7.30 & 7.20 & 7.07 & 0.83 \\
\hline
\end{tabular}


Table (3): FLACC score changes in the three groups.

\begin{tabular}{lccccccc}
\hline & $1 \mathrm{hr}$ & $2 \mathrm{hr}$ & $4 \mathrm{hr}$ & $6 \mathrm{hr}$ & $10 \mathrm{hr}$ & $12 \mathrm{hr}$ & $24 \mathrm{hr}$ \\
\hline$p$-value & 0.319 & 0.136 & $<0.001 *$ & 0.068 & $0.002 *$ & 0.673 & 0.176 \\
GI \& GII & 0.492 & 0.112 & $<0.001 *$ & 0.248 & $<0.001 *$ & 0.671 & 0.945 \\
GI \& GIII & 0.132 & 0.080 & $<0.001 *$ & 0.124 & 0.286 & 0.812 & 0.156 \\
GII \& GIII & 0.393 & 0.789 & 0.081 & 0.640 & $0.032 *$ & 0.314 & 0.073 \\
\hline
\end{tabular}

Table (4): Total dose (mg) of analgesia comparison between three groups.

\begin{tabular}{llll}
\hline & Group I & Group II & Group III \\
\hline Mean & 448 & 275.66 & 339.33 \\
SD & 97.65 & 73.38 & 108.50 \\
$p$-value & & $0.0001^{*}$ & \\
GI \& GII & & $0.0001^{*}$ & \\
GI \& GIII & & $0.0001^{*}$ & \\
GII \& GIII & & $0.012^{*}$ & \\
\hline
\end{tabular}

Table (5): Time (hr) of first rescue analgesia comparison between three groups.

\begin{tabular}{lllc}
\hline & Group I & Group II & Group III \\
\hline Mean & 4.6 & 11.8 & 8.13 \\
SD & 0.92 & 3.40 & 2.00 \\
$p$-value & & $0.0001^{*}$ & \\
GI \& GII & & $0.0001^{*}$ & \\
GI \& GII & & $0.0001^{*}$ & \\
GII \& GIII & & $0.0001^{*}$ & \\
\hline
\end{tabular}

Table (6): Side effect comparison between three groups.

\begin{tabular}{llllc}
\hline & Group I & Group II & Group III & $p$-value \\
\hline - Vomiting & $2(6.66 \%)$ & $3(10 \%)$ & $2(6.66 \%)$ & 0.85 \\
- Urinary retention & $2(6.66 \%)$ & $1(3.33 \%)$ & $1(3.33 \%)$ & 0.76 \\
- Motor deficit, Sensory deficit, Respiratory & 0 & 0 & 0 & \\
depression, Systemic toxicity, Bradycardia & & & & \\
\hline
\end{tabular}

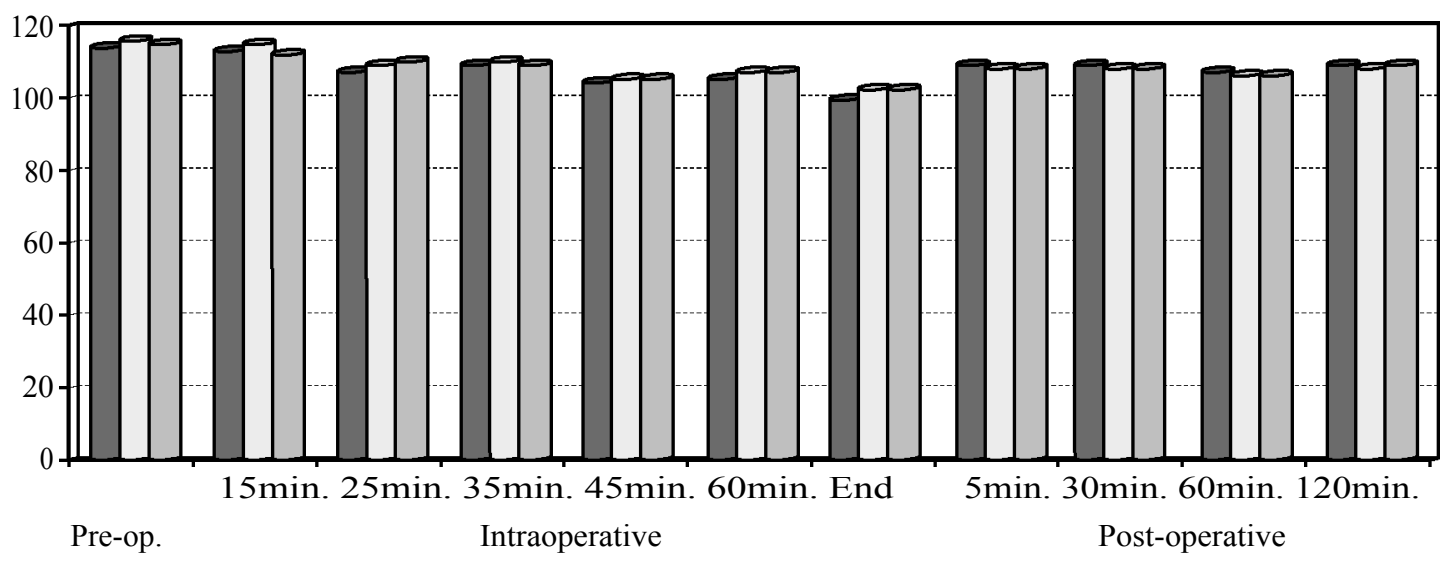

Fig. (1): Heart rate (beat/min) comparison between groups.

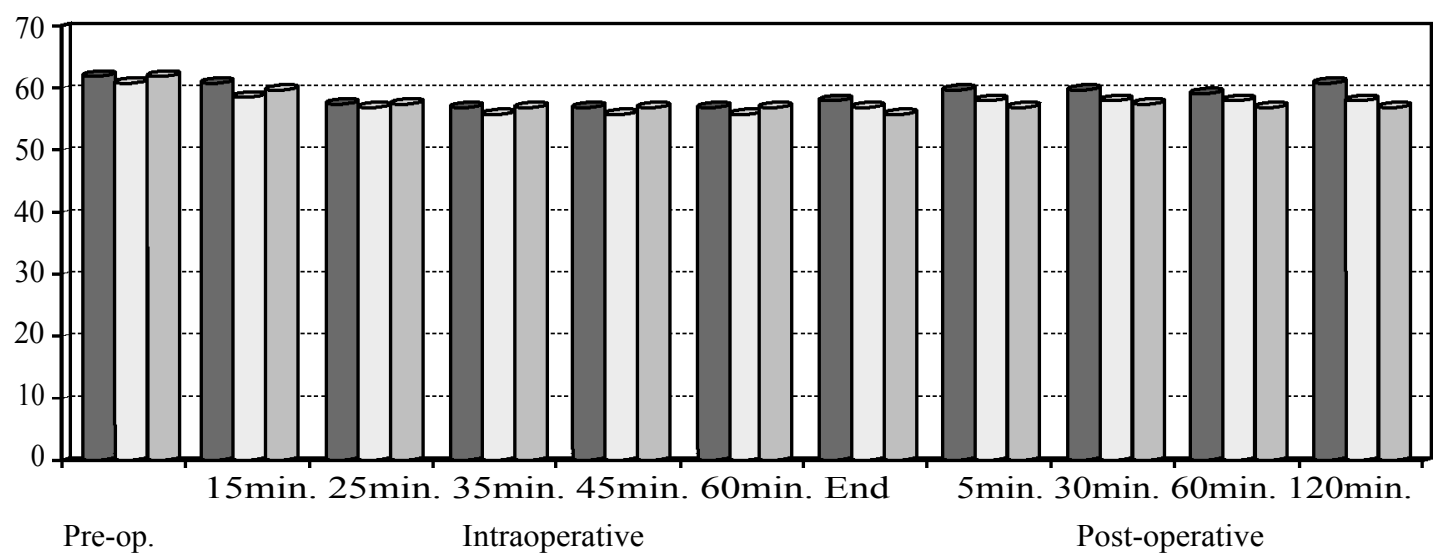

Fig. (2): Mean arterial blood pressure ( $\mathrm{mm} \mathrm{Hg}$ ) comparison between three groups. 


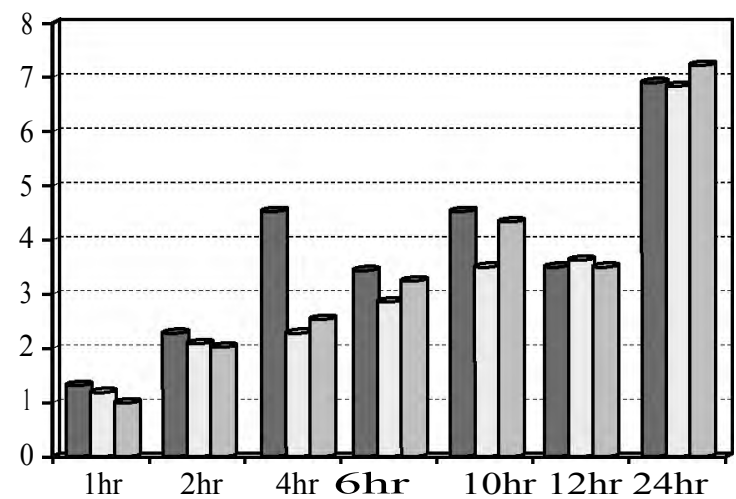

Fig. (3): FLACC comparison between three groups.

\section{Discussion}

The results of the present study showed that there was a statistically significant difference between pre-operative hemodynamics (HR \& MAP) and hemodynamics from 25 minutes intraoperative and till the end of operation $\&$ at all times post-operative in group I patients who received bupivacaine $0.25 \%$ only, group II patients who received caudal bupivacaine $0.25 \%$ with dexmedetomidine $2 \propto \mathrm{g} / \mathrm{kg}$ and in group III who received caudal bupivacaine $0.25 \%$ with neostigmine $2 \propto \mathrm{g} / \mathrm{kg}(p$-value $<0.05)$. There was no a statistically significant difference between (group I \& group II), (group I \& group III) and (group II $\&$ group III) in hemodynamics at all times intraoperative and till the end of operation $\&$ at all times post-operative $(p$-value $<0.05)$.

In agreement with Saadawy et al., [14], who compared the effect of caudal injection of $1 \mathrm{ml} / \mathrm{kg}$ of bupivacaine $2.5 \mathrm{mg} / \mathrm{ml}$ and the same dose of bupivacaine mixed with Dex $1 \mathrm{mic} / \mathrm{kg}$ in patient undergoing unilateral inguinal hernia repair or orchidopexy, this study reported decrease in HR and MAP in dexmedetomidine group. However, the hemodynamic effects did not reach statistically significant values between groups during the study period.

Also, Nasr et al., [15] . Compared the efficacy of the caudal dexmedetomidine or caudal fentanyl on the stress response and post-operative analgesia and concluded that the HR \& MAP were significantly decreased in the dexmedetomidine group.

Also, this was in agreement with Abdulatif et al., [9], who reported better perioperative hemodynamics with the use of the caudal bupivacaine/ neostigmine mixture rather than bupivacaine or neostigmine alone, also the addition of neostigmine to bupivacaine resulted in superior analgesia compared with the other two groups and the recovery to first analgesic times was also prolonged in such group compared to the other two groups.

In contrast to this study Taheri et al., [16], also compared caudal block with either $0.25 \%$ bupivacaine $(1 \mathrm{ml} / \mathrm{kg})$ with neostigmine $2 \propto \mathrm{g} / \mathrm{kg}$ or tramadol $1 \mathrm{mg} / \mathrm{kg}$, found that the mean arterial blood pressure during the 1 st $24 \mathrm{hr}$ after extubation to be significantly lower in the neostigmine group.

Our study was in agreement, Kumar et al., [4], found no differences in heart rate or mean arterial blood pressure between $0.25 \%$ bupivacaine $(1 \mathrm{ml} /$ $\mathrm{kg}$ ) alone or bupivacaine $0.25 \%$ with ketamine $0.5 \mathrm{mg} / \mathrm{kg}$, midazolam $50 \propto \mathrm{g} / \mathrm{kg}$ or neostigmine $2 \propto \mathrm{g} / \mathrm{kg}$.

Memis et al., [17], found no significant differences in heart rate or mean arterial blood pressure between $0.25 \%$ bupivacaine $(0.5 \mathrm{ml} / \mathrm{kg})$ and $0.25 \%$ bupivacaine $(0.5 \mathrm{ml} / \mathrm{kg})$ with neostigmine $1 \propto \mathrm{g} / \mathrm{kg}$ in children subjected to elective inguinal hernia and hypospadias surgeries.

Similarly, Mahajan et al., [18], in their study titled "caudal neostigmine with bupivacaine produces a dose-independent analgesic effect in children" to evaluate the analgesic efficacy and duration of varying doses of caudal neostigmine with bupivacaine in children undergoing genito-urinary surgery, compared caudal injection of only $0.25 \%$ bupivacaine $(0.5 \mathrm{ml} / \mathrm{kg})$ and $0.25 \%$ bupivacaine $(0.5 \mathrm{ml} / \mathrm{kg})$ with neostigmine in doses of 2,3 and $4 \propto \mathrm{g} / \mathrm{kg}$. They reported no significant differences in heart rate or mean blood pressure between the four groups. However, mean time to first administration of rescue analgesia was significantly prolonged in the neostigmine groups compared to the bupivacaine only group.

Dutt et al., [19] concluded that hemodynamics was comparable between fentanyl or dexmedetomidine to caudal ropivacaine in pediatrics underwent lower abdominal and lower limb surgeries.

As regard pain assessment, this study assessed the pain by FLACC scale which was significantly increased within the same group at different measurement times in the three groups. The FLACC pain score was significantly lower in dexmedetomidine group than bupivacaine only group. The FLACC pain score was significantly lower in neostigmine group than bupivacaine only group. The FLACC pain score was significantly lower in dexmedetomidine group than neostigmine group.

As regard in time of first rescue analgesia, in this study it was faster in group I than in group III 
than in group II. As regard in amount of total dose of analgesia this study showed that the requirement of analgesia was more in group I than in group III than in group II.

In agreement with our study, El-Hennawy et al., [20] found that the duration of analgesia was significantly higher in the group receiving bupivacaine-dexmedetomidine mixture and found also that the FLACC scale was significantly lower in that group than the bupivacaine alone administered group.

Kumar et al., [4] found that the duration of absolute analgesia and the time to first analgesic was significantly prolonged in the group that received bupivacaine neostigmine in comparison with that had bupivacaine alone and also with that had bupivacaine midazolam or bupivacaine ketamine.

Also, Abdulatif and Sanabaru [9] in their study to examine the analgesic efficacy of caudal neostigmine, bupivacaine, or mixture of both drugs, showed that caudal administration of bupivacaine with the addition of neostigmine resulted in superior analgesia compared with the other two groups and the recovery to first analgesic times was also prolonged in such group compared to the other two groups.

Another study done by Mahajan et al., [18] found that mean time to first administration of rescue analgesia was significantly prolonged in the neostigmine groups compared to the bupivacaine only group.

Though they used different pain scores, the FLACC score has excellent reliability and validity. The extent to which results are consistent over time and an accurate representation of the total population under study is referred to as reliability and if the results of a study can be reproduced under a similar methodology, then the research instrument is considered to be reliable. Validity determines whether the research truly measures that which it was intended to measure or how truthful the research results are.

As regard time to first rescue analgesic in this study, the mean value of time till the first rescue analgesia in group I was 4.6 hours, in group II was 11.8 hours while in group III was 8.1 hours.

In this study, the mean value of total dose rescue analgesic (acetaminophen) in 24-hour postoperative in group I was $448 \mathrm{mg}$, in group II was $275.6 \mathrm{mg}$, in group III was $339.3 \mathrm{mg}$.
In agreement with our study, Neogi et al., [21] compared clonidine $1 \mathrm{~g} / \mathrm{kg}$ and dexmedetomidine $1 \mu / \mathrm{kg}$ as adjuncts to ropivacaine $0.25 \%$ for caudal analgesia in pediatric patients and concluded that addition of both clonidine and dexmedetomidine with ropivacaine administered caudally significantly increases the duration of analgesia.

Xiang et al., [8], concluded that the supplementation of caudal bupivacaine with dexmedetomidine reduces the response to hernia sac traction in the inguinal hernia repair in pediatric surgery, besides it prolongs the duration of post-operative analgesia and decrease the rescue analgesia post-operative.

As regard to post-operative complication, the result of our study showed no significant incidence of vomiting or urine retention in the three groups.

In agreement with our study, Anand et al., [22], who observed that patients receiving caudal dexmedetomidine $2 \mu \mathrm{g} / \mathrm{kg}$ with $0.25 \%$ ropivacaine $1 \mathrm{ml} / \mathrm{kg}$ for paediatric lower abdominal surgeries had significant post-operative pain relief up to 15 hours without any significant side effects.

In consistent with our results, Kumar et al., [4], reported that the incidence of vomiting was the same in those who received bupivacaine only, bupivacaine neostigmine, bupivacaine ketamine and bupivacaine midazolam.

\section{Conclusions:}

Addition of dexmedetomidine to bupivacaine in a dose of $2 \mu \mathrm{g} / \mathrm{kg}$ results in superior analgesia than bupivacaine alone. Also, addition of neostigmine to bupivacaine in a dose of $2 \mu \mathrm{g} / \mathrm{kg}$ results in superior analgesia than bupivacaine alone.

Addition of dexmedetomidine to bupivacaine had better analgesic effect than addition of neostigmine to bupivacaine.

Conflicts of interest: No conflicts of interest declared.

Authors' contributions: All authors had equal role in design, work, statistical analysis and manuscript writing.

\section{References}

1- WEKSLER N., ATIAS I., KLEIN M., ROSENZTSVEIG V., OVADIA L., et al.: Is penile block better than caudal epidural block for postcircumcision analgesia? Journal of Anesthesia, 19 (1): 36-9, 2005.

2- HANSEN T.G., HENNEBERG S.W., WALTHERLARSEN S., LUND J. and HANSEN M.: Caudal bupivacaine supplemented with caudal or intravenous clonidine in children undergoing hypospadias repair: A double- 
blind study. British Journal of Anaesthesia, 92 (2): 223 7, 2004.

3- SANDERS J.: Paediatric regional anaesthesia, a survey of practice in the United Kingdom. British Journal of Anaesthesia, 89 (5): 707-10, 2002.

4- KUMAR P., RUDRA A., PAN A.K. and ACHARYA A.: Caudal additives in pediatrics: A comparison among midazolam, ketamine, and neostigmine coadministered with bupivacaine. Anesthesia \& Analgesia, 101 (1): 6973, 2005.

5- De BEER D. and THOMAS M.: Caudal additives in children-solutions or problems? British Journal of Anaesthesia, 90 (4): 487, 2003.

6- SINGH R., KUMAR N. and SINGH P.: Randomized controlled trial comparing morphine or clonidine with bupivacaine for caudal analgesia in children undergoing upper abdominal surgery. British Journal of Anaesthesia, 106 (1): 96-100, 2011.

7- HALL J.E., UHRICH T.D., BARNEY J.A., ARAIN S.R and EBERT T.J.: Sedative, amnestic, and analgesic properties of small-dose dexmedetomidine infusions. Anesthesia \& Analgesia, 90 (3): 699-705, 2000.

8- XIANG Q., HUANG D., ZHAO Y., WANG G., LIU Y., et al.: Caudal dexmedetomidine combined with bupivacaine inhibit the response to hernial sac traction in children undergoing inguinal hernia repair. British Journal of Anaesthesia, aes385, 2012.

9- ABDULATIF M. and EL-SANABARY M.: Caudal neostigmine, bupivacaine, and their combination for postoperative pain management after hypospadias surgery in children. Anesthesia \& Analgesia, 95 (5): 1215-8, 2002.

10-DUTT B., PARMAR N.K., SHRIVASTAVA M., DHAMA V., TYAGI V., et al.: Comparison of caudal dexmedetomidine and fentanyl for postoperative analgesia: A randomized double blind study. Journal Of Advance Researches In Medical Sciences (Formerly Journal of Advance Researches in Biological Sciences), 6 (1): 51-7, 2014.

11- MALVIYA S., VOEPEL-LEWIS T., BURKE C., MERKEL S. and TAIT A.R.: The revised FLACC observational pain tool: Improved reliability and validity for pain assessment in children with cognitive impairment. Pediatric Anesthesia, 16 (3): 258-65, 2006.

12- TSUI B.C. and BERDE C.B.: Caudal analgesia and anesthesia techniques in children. Current Opinion in Anesthesiology, 18 (3): 283-8, 2005.
13- PASSARIELLO M., ALMENRADER N., CANNETI A., RUBEO L., HAIBERGER R., et al.: Caudal analgesia in children: $S(+)$-ketamine vs $S(+)$-ketamine plus clonidine. Pediatric Anesthesia, 14 (10): 851-5, 2004.

14- SAADAWY I., BOKER A., ELSHAHAWY M., ALMAZROOA A., MELIBARY S., et al.: Effect of dexmedetomidine on the characteristics of bupivacaine in a caudal block in pediatrics. Acta anaesthesiologica Scandinavica, 53 (2): 251-6, 2009.

15- NASR D.A. and ABDELHAMID H.M.: The efficacy of caudal dexmedetomidine on stress response and postoperative pain in pediatric cardiac surgery. Annals of cardiac anaesthesia, 16 (2): 109, 2013.

16- TAHERI R., SHAYEGHI S., RAZAVI S.S., SADEGHI A., GHABILI K., et al.: Efficacy of bupivacaineneostigmine and bupivacaine-tramadol in caudal block in pediatric inguinal herniorrhaphy. Pediatric Anesthesia, 20 (9): 866-72, 2010.

17- MEMIŞ D., TURAN A., KARAMANLIO GLU B., KAYA G., SÜT N., et al.: Caudal neostigmine for post-operative analgesia in paediatric surgery. Pediatric Anesthesia, 13 (4): 324-8, 2003.

18- MAHAJAN R., GROVER V.K. and CHARI P.: Caudal neostigmine with bupivacaine produces a dose-independent analgesic effect in children. Canadian Journal of Anesthesia, 51 (7): 702, 2004.

19-DUTT B., PARMAR N.K., SHRIVASTAVA M., DHAMA V., TYAGI V., et al.: Comparison of caudal dexmedetomidine and fentanyl for post-operative analgesia: A randomized double blind study. Journal of Advance Researches In Medical Sciences, 6 (1): 51-7, 2014

20- EL-HENNAWY A., ABD-ELWAHAB A., ABDELMAKSOUD A., EL-OZAIRY H. and BOULIS S.: Addition of clonidine or dexmedetomidine to bupivacaine prolongs caudal analgesia in children. British Journal of Anaesthesia, 103 (2): 268-74, 2009.

21- NEOGI M., BHATTACHARJEE D.P., DAWN S. and CHATTERJEE N.: A comparative study between clonidine and dexmedetomidine used as adjuncts to ropivacaine for caudal analgesia in paediatric patients. Journal of Anaesthesiology Clinical Pharmacology, 26 (2): 149, 2010

22- ANAND V.G., KANNAN M., THAVAMANI A. and BRIDGIT M.J.: Effects of dexmedetomidine added to caudal ropivacaine in paediatric lower abdominal surgeries. Indian Journal of Anaesthesia, 55 (4): 340, 2011. 


\section{مقارنة بين عقار الديكسميديتوميدين وعقار النيوستجمين الئين

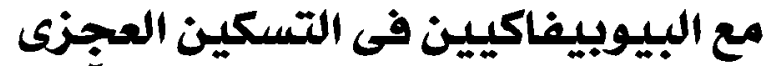

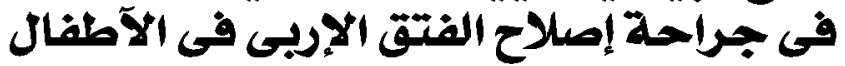

المقدمة: يعد معالجة الآلم بعد العملية الجراحية عند الآطفال ضرودة لآسباب طبية وآخلاقية. يستخدم التخدير العجزى مع التخدير الكلى على نظاق واسع لتسكين الآلم.

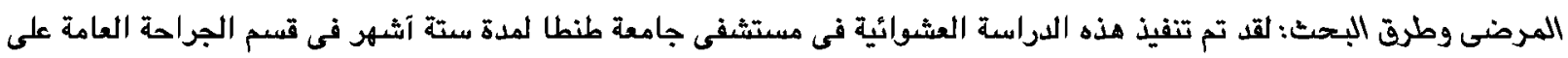

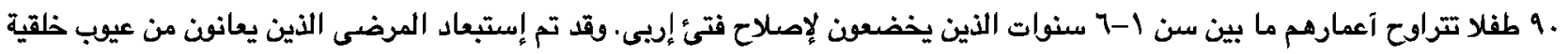

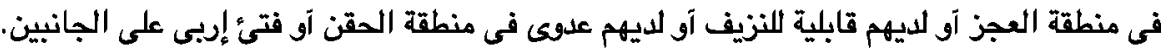

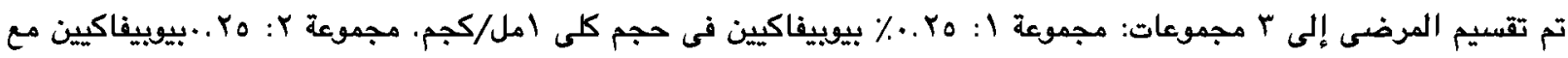

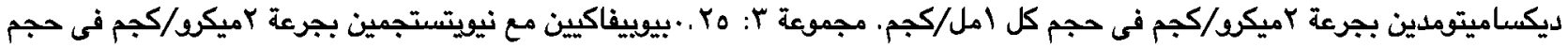
ا ملل/كجم.

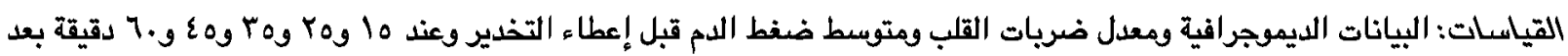

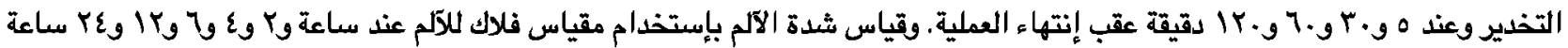

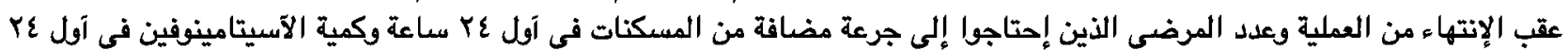

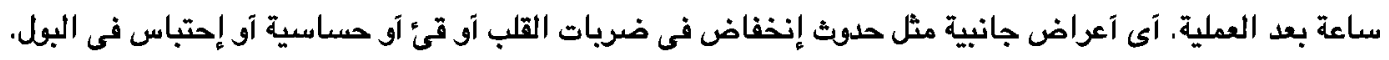

الملخص: معدلات ضريات القلب ومتوسط الضفط كانت إحصائيا آتل فى المجموعة الثالثة مقارنة بالمجموعة الثانية مقارنة بالمجموعة 